\title{
Acknowledgements
}

It is with great joy and deep gratitude that I acknowledge the individuals and institutions whose support has been crucial to the publication of this book. For financial support, I thank the Aberystwyth University Postgraduate Research Fund; the German Academic Exchange Service (Deutscher Akademischer Austauschdienst); the German History Society; the Partners in Confronting Collective Atrocities Group; the Society for Historians of American Foreign Relations; the Postdoctoral Fellowship Fund of the Foreign Ministry of the State of Israel; the Memorial House of the Wannsee Conference Joseph Wulf Fellowship Fund; and the Research Institute at the Department of History and Art History at Utrecht University. All of these provided fundamental resources that allowed me to conduct the research for this book across Europe, the United States and the Middle East.

I thank the University of Roma Tre for having granted me, in the very distant past, a scholarship to conduct research abroad to write my undergraduate dissertation on German foreign policy - that experience had a profound impact on me, and the double effect of both rewarding and further unleashing my intellectual curiosity. I would have never embarked upon this journey without Leopoldo Nuti's lectures, which introduced me to a wonderful and complex subject, la storia delle relazioni internazionali, which I now teach at Utrecht University and where I am proud to be a member of a wonderful group of historians who made me feel welcome in the Netherlands from my very first day. In particular, I am grateful to the members of the History of International Relations section, and especially to Beatrice de Graaf, Laurien Crump, Jacco Pekelder, Liesbeth van de Grift and Jolle Demmers; to research director Oscar Gelderblom and research coordinator Tom Gerritsen; and to the successive directors of the Department of History and Art History, Leen Dorsman, Josine Blok and Maarten Prak, for having supported me in countless ways.

Pursuing my studies at the London School of Economics and at Aberystwyth University taught me more than I could have hoped for. I am especially grateful to Campbell Craig and R. Gerald Hughes, for their unwavering confidence in this project and in my abilities to pursue it successfully. Jenny Edkins, Kamila Stullerova, Jan Ruzicka, Peter Lambert, Claudia Hildebrand and Sergey Radchenko all provided helpful guidance. At the LSE International Relations Department, I was greatly inspired by conversations with Fawaz Gerges, Kristina Dalacoura, Christopher Coker, George Lawson and Ulrich Sedelmeier, and I would have not embarked upon my research without Kimberly Hutchings' gentle encouragement.

Visiting research fellowships in Germany and Israel were, in innumerable ways, crucial in allowing me to develop the argument of this book. At the Jena Center for 20th Century History I was immersed in a lively research environment which 
profoundly shaped my thinking on German contemporary history. I was greatly inspired by my conversations with Norbert Frei, Kristina Meyer, Dominik Rigoll, Tobias Freimüller, Jacob Eder, Janine Gaumer and Annette Weinke, and it is with pleasure that I note that many of these conversations are still ongoing. At the Joseph Wulf Library of the Memorial House of the Wannsee Conference, I have greatly benefited from conversations and exchanges with Hans-Christian Jasch, Christoph Kreuzmüller and Monika Sommerer. During my time in Israel, I have learnt a great deal from Moshe Zimmermann, Yehuda Bauer, Manuela Consonni, Juliane Brauer, David Witzthum, Guy Laron, Tibor Shalev-Schlosser, Shlomo Shpiro, Hilla Lavieh and Irit Chen. I am in great debt to all the members of the Richard Koebner Minerva Center for German History at the Hebrew University in Jerusalem, but in particular to Ofer Ashkenazi, who provided me with moral, logistical and intellectual support as well as a desk with the most beautiful view of Jerusalem I ever could have imagined, which turned out to be a perfect location for me to finish writing this book.

I am very grateful to all the archivists in Germany, Israel, the UK, the Netherlands, Italy, Austria and the United States who have helped me with my research.

The conversations with eyewitnesses and archivists, as well as with colleagues, friends and mentors, have been a constant source of inspiration. I owe special thanks to Andrew Monaghan, Fawaz Gerges, Oliver Rathkolb, Mark Kramer, Holger Nehring, Stephan Malinowski, Jeffrey Herf, Sybille Steinbacher, Emile Chabal, Roham Alvandi, Piers Ludlow, Jonathan A. Bush, Giles Scott-Smith, Donald Abenheim, Judith Keilbach, Galia Golan, Cian O’Driscoll, Sielke B. Kelner, Turlach O Broin, Ivor Bolton, James Hershberg, Markus Görannson, Aidan Condron, Corina Mavrodin and Ned Richardson-Little. Throughout the years, I have had the privilege of sharing my ideas in fieri at international conferences and workshops with talented scholars, whose questions and comments have helped greatly in refining my thinking on the issues I write about in this monograph. I am grateful to those who contributed during discussions at the International Politics Research Seminar at Aberystwyth University; the London School of Economics' International History Seminar; the Cold Warriors discussion at Sciences Po Paris; the Centre for the Study of Modern and Contemporary History at the University of Edinburgh; the German Historical Institute (London); the British Academy; the Partners in Confronting Collective Atrocities experiential conference (2012); the Doktorandenschule seminars of the Jena Center for 20th Century History; Charles University in Prague; the Forschungskolloquium of the Fritz Bauer Institut at the Goethe University Frankfurt; the Hebrew University in Jerusalem; and the conferences of the Society for Historians of American Foreign Relations, the Political Studies Association, the Practice of International History in the 21st Century Network, and the New Diplomatic History Network. I am indebted to Jacob Eder and Hubert Leber, who organised the 2014 conference on German-Jewish-Israeli relations at the University of Haifa with the support of the ZEIT Stiftung Ebelin und Gerd Bucerius, providing me with the opportunity to share panels and ideas with some of my academic heroes; and I owe special thanks also to the organisers of the European Summer School on Cold War History and the German Academic Exchange Service 
Summer School in German Studies for having provided me with an opportunity to present some of my preliminary findings. I am also profoundly grateful to the Institute for German Studies at Birmingham University, and especially its director Nick Martin, for having agreed to support my organisation of a Symposium on '50 Years of German-Israeli Relations: Reflections on History, Memory and International Politics'. I am especially grateful to Amb. Harald Kindermann and Amb. Shimon Shtein for having agreed to share crucial insights based on their ambassadorial experience in Israel and Germany, respectively, and to Ruth Wittlinger for her insightful comments. Ruth's premature passing away has come as a shock to me. I hope that this book will serve as a testimony to just how inspiring she has been for many young scholars.

It is a privilege to work with bright, engaged and inquisitive students. I was humbled by the invitation from Sjoerd van Hoenselaar on behalf of the members of the Utrechtse Historische Studentenkring (UHSK study association) to accompany and guide a group of undergraduate and postgraduate students in their visit to Munich and to the Dachau concentration camp. That was an experience that I, as an educator, will never forget. I should also like to thank Celine Mureau, Martijn Kool, Belinda Borck, Yiftach Shavit, Mikulas Pesta and Marcus Chavasse for helping me check some of the references in Dutch, German, Russian, Czech, Hebrew and Arabic and for acting as my sounding boards as I developed the core ideas of the book. And I will never forget the day Frau Donini walked up to me, introducing herself nonchalantly in German. I thank her for having helped me to understand, that morning of many years ago, that die Grenzen meiner Sprache bedeuten die Grenzen meiner Welt, and that it was possible - even fun - to keep pushing those Grenzen further and further. I am also deeply grateful for having encountered exceptionally wonderful friends during my extensive travelling. They all taught me much, warmly welcoming me into their worlds and making me a much richer person for it. E naturalmente non sarei riuscita a fare nemmeno un passo in terra straniera se non avessi saputo che dietro di me c'era e c'è un appoggio incrollabile, formato da coloro che in Italia mi sostengono e stravedono per me. Grazie di cuore a tutti voi.

\section{Note on translations and transliterations}

In the transliteration of names of persons and locations from Arabic, Hebrew, German, Czech and Russian I have chosen to use the transliterations prevalent in common English usage for the sake of clarity. I have received the support of Hagit Kleve and Yiftach Shavit for translations from Hebrew and Arabic; from Marcus Chavasse for translations from Russian; and from Mikulas Pesta for translations from Czech. All translations from German, Dutch, French, Spanish and Italian are my own, unless otherwise stated. 